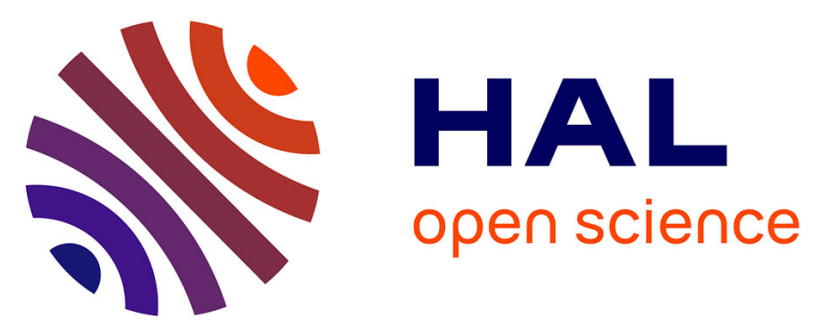

\title{
Nexus Between Country Context and the Role of External Actors in the Formulation of National Information and Communication Technology Policies
}

Gregory Kunyenje, Wallace Chigona

\section{- To cite this version:}

Gregory Kunyenje, Wallace Chigona. Nexus Between Country Context and the Role of External Actors in the Formulation of National Information and Communication Technology Policies. 15th International Conference on Social Implications of Computers in Developing Countries (ICT4D), May 2019, Dar es Salaam, Tanzania. pp.151-167, 10.1007/978-3-030-19115-3_13 . hal-02281328

\author{
HAL Id: hal-02281328 \\ https://hal.inria.fr/hal-02281328
}

Submitted on 9 Sep 2019

HAL is a multi-disciplinary open access archive for the deposit and dissemination of scientific research documents, whether they are published or not. The documents may come from teaching and research institutions in France or abroad, or from public or private research centers.
L'archive ouverte pluridisciplinaire HAL, est destinée au dépôt et à la diffusion de documents scientifiques de niveau recherche, publiés ou non, émanant des établissements d'enseignement et de recherche français ou étrangers, des laboratoires publics ou privés. 


\title{
Nexus between country context and the role of external actors in the formulation of national Information and Communication Technology policies
}

\author{
Gregory Kunyenje ${ }^{1[0000-1111-2222-3333]}$ and Wallace Chigona ${ }^{\text {[11111-2222-3333-4444] }}$ \\ ${ }^{12}$ University of Cape Town, Rondebosch, South Africa \\ knygre001@myuct.ac.za; wallace.chigona@uct.ac.za
}

\begin{abstract}
This paper examines the nexus between the context of a developing country and external actors' influence in the formulation of a national Information and Communication Technology (ICT) policy. It questions whether context of a country affects the way external actors influence formulation of a national ICT policy following that external actors have mostly influenced policy formulation in Africa. Drawing on Bourdieu's concepts of field, habitus, capital and practice, the study uses eighteen interview transcripts, three draft policy documents, two copies of minutes of policy meetings and three reports to analyse the relationship. The paper finds that external actors overtly influence the formulation of a national ICT policy in developing countries with limited economic, social and cultural capital. This finding offers stakeholders of public policy and government important insights into how they can effectively manage external actors during the policy process in developing countries.
\end{abstract}

Keywords: National ICT policy, External influences, Malawi, Country context.

\section{Introduction}

A national ICT policy is a specification of objectives intended to direct and control implementation of ICTs in a country [39]. National ICT policies are important towards realising a country's socio-economic goals such as enhancing democracy and the general diffusion of ICTs, among other applications [45].

Nearly 84\% of countries in Africa have formulated national ICT policies [1], most of which have been influenced by external actors [35]. During policy formulation, however, these actors played other roles such as providing blueprints for developing national ICT policies [1] and setting priorities for policy and action [50]. In the process, the external actors either endorsed, undermined or actively facilitated "the entry of different actors and interests depending on their national ideologies or interests" [19, p.6]. Influence denotes motivation, resources, expertise and power balance during a national ICT policy making.

Malawi, a country in Africa, has been overtly influenced by external actors in the formulation of its national ICT policy. The influences include provision of financial 
support [29] and technical assistance [16]. UNDP funded a pre-policy survey in Malawi in 2002 to establish the levels of ICT utilisation at district and national levels [29]. UNDP also funded workshops in early 2002, which were aimed at soliciting views from stakeholders regarding the ICT policy framework that Malawi would adopt [34], despite literature discouraging imposing of policy ideas on a country [44]. Furthermore, the process of developing the Malawi policy was highly convoluted going through three different drafts over a decade before the policy could be adopted [33]. Malawi launched its first national ICT policy in 2013 [24].

Although there is a substantial body of qualitative research that has focused on external actors' influences in national ICT policy making in Africa [1]; [10]; [19]; [33]; [35], there is a dearth of research that has attempted to focus on the effects of the influences. This paper aims at extending previous research on external actors' influences by analysing how the context of a developing country affects the influence of external actors in the formulation of national ICT policies. An examination of the nexus between country context and influence of external actors in policy making may help unlock the mystery surrounding the reported poor ICT policy outcomes in developing countries. The analysis may also help stakeholders of public policy in developing countries to devise strategies for managing external actors during the policy process. The paper seeks to answer the research question: How does country context affect the way external actors influence formulation of a national ICT policy of a developing country?

Bourdieu's Theory of Practice was adopted because of its focus on aspects of domination and relative strength of agents within social space [5]. External actors' influences in the formulation of a national ICT policy are deemed to have resulted in some forms of domination [30]. Documents and interviews with policy actors from Malawi were used for the study. Malawi was selected as the case on the basis that it is heavily reliant on donors for foreign aid [48]. World Bank reports also show that poverty levels in Malawi are in excess of $70 \%$ of the population [47]. With this status, there is a possibility that donors may influence the country's policies given its context.

The paper is structured as follows. Section 2 outlines the literature that was reviewed for the study. Sections 3 and 4 describe the theoretical framework that was adopted and the methodology used for the research. Section 5 provides a description of the case study. Section 6 is an outline of the results. Section 7 discusses findings and concludes the study.

\section{$2 \quad$ Literature review}

\subsection{Policy Process}

Nearly all public policy models suggest a stages approach to the policy process, which include agenda setting, policy formulation, policy adoption, policy implementation and policy evaluation [15]. The problem or issue of concern is identified in 
agenda setting [32]. Within the same stage, challenges and opportunities associated with the agenda are then defined. In most models, agenda setting entails local actors identifying problems that have to be addressed since they are conversant with the social problem to be addressed. Next, goals and objectives are formulated to address the challenges.

The third stage involves four steps: (i) formal consultation, (ii) risk analysis, (iii) undertaking pilot studies, and (iv) designing the implementation plan. The fourth stage deals with implementation of the policy and may include development of legislation and a delivery plan to support the implementation of the formulated policy [4]. The last stage deals with an assessment of the policy objectives to determine if they are effective in addressing the challenges [15]. This is one stage in which consequences of a policy are understood in a real life situation [11]. After this stage, the process may re-start. Although the policy process is conceptualized as sequential, in reality it consists of iterative processes [32]. This study focused on the policy formulation stage because most forms of external actors' influences were identified in this stage [30].

\subsection{Policy Making and Policy Actors in Africa}

External actors mostly influence policy formulation in most developing countries. Research on the political economy of ICT policy making in Africa noted that most policies and ICT programme agendas are influenced by external actors rather than through participatory activities within the countries [1]. Similarly, [21] reviewed matters of ICT policy research and attributed poor ICT policy outcomes in Africa to the scarcity of critical research that considers political dimensions of policy reform and economic regulation. The review established that external actors initiated the policy reforms instead of local actors, a practice that has been discouraged in literature [44].

The idea to formulate national ICT policies dates back to 1993 when the first National Information Infrastructure (NII) was established in the United States of America [1]. By the mid-1990s, the NII initiative gave birth to national and regional information society initiatives around the globe. The African Information Society Initiative (AISI) was set up in 1996 with support from the United Nations Economic Commission for Africa (UNECA) and other international organisations [10]. Consequently, the AISI developed a National Information Communication Infrastructure (NICI) framework as a blueprint for formulating national ICT policies in Africa [1]. This is a form of external influence.

Public policies are the effort of a network of actors [4]. A policy network is a group of actors that are recruited to take part in policy making [37]. Policy actors can be classified based on whether they are visible or invisible [37]; official or unofficial [4] or based on their place of origin such as foreign or local actors [35]. The term foreign actors has been used interchangeably with external actors [35]. Policy actors have also been classified into local, domestic and external actors where domestic have represented actors that take part in regional policy making activities [10]. This study classifies policy actors as nationals that were appointed into a policy network to take 
part in policy making activities and external as those actors who were not nationals of a country (see Error: Reference source not found).

Table 1: Classification of policy actors based on their position vis-a-vis the policy network [10]

\begin{tabular}{lll}
\hline $\begin{array}{l}\text { Category of } \\
\text { Actor }\end{array}$ & Definitions & Examples of Actors \\
\hline Local actors & $\begin{array}{l}\text { Nationals from a country ap- } \\
\text { pointed in a policy network }\end{array}$ & $\begin{array}{l}\text { Actors from Public actors, Private ac- } \\
\text { tors and local non-governmental or- } \\
\text { ganisations } \\
\text { External actors }\end{array}$ \\
& $\begin{array}{l}\text { Bilateral donors, international international organisations } \\
\text { organisations and regional } \\
\text { groupings and other countries }\end{array}$ & $\begin{array}{l}\text { and regional groupings and other } \\
\text { countries }\end{array}$ \\
\hline
\end{tabular}

In normal circumstances, government is the main actor in public policy making, even in situations where ideas come from other actors [4]. Government sets agenda by filtering issues and problems that are to be solved [37]. However, formulation of public policies in Africa, a stage which follows agenda setting, attracts external actors. The external actors in policy making activities in Africa have been either visible or invisible [10]; [35].

\subsection{National Information and Communication Infrastructure}

The NICI approach consists of a framework, policy, plan and structures [16]. The framework is a platform for setting the agenda to develop the policy, plan and structures [16]. The plan outlines details of programmes and initiatives for implementing government commitments while the structures deal with bodies or institutional arrangements that support formulation and implementation of the policies and plans [16].

The framework became a blueprint for developing national ICT policies in African countries and was created to fast track inclusion of Africa into the global information society through development of "national ICT policies, strategies and plans" [10, p.10]. To date, $56 \%$ of countries in Africa have used the blueprint to develop their national ICT policies [1]. Despite this revelation, not much has been done to explore how country context is related to the influence of external actors in ICT policy making.

\subsection{Influence of External Actors}

External actors' influences in the formulation of national ICT policies in Africa include the NICI framework, financial support, technical support and policy ideas [30]. The influences were categorised as direct where a local actor had direct contact with an external actor and indirect where there was no direct contact during policy making. [35] classified technical and financial support as direct influences and situations where external actors controlled policy formulation from behind-the-scenes in the case of Swaziland, as indirect influences. The influences together with their categorization do not reveal much about the effects of external actors on policy. 


\subsection{Country Context on Policy}

Public policy studies in other disciplines present diverse findings on effects of context on policy. An evaluation on the effect of context on climate change adaptation policy found that contextual factors influence effectiveness of national energy conservation measures [43]. Another study on effect of context on family policy highlighted "both the potential of systematic interventions in parenting, peer relations, and socialcognitive skills training, and the problems that will be encountered in trying to bring these interventions to a community context” [14, p.443] as factors that may affect policy. These studies appear to suggest that each discipline may have its own contextual factors that can determine the effectiveness of a policy.

The importance of country context in ICT projects has been discussed in research. A study on E-government implementation in sub-Saharan Africa found that institutional, cultural, and administrative contexts are prerequisites for the success of ICTs [41]. This study focused on the implementation and use of ICTs, which are goals of a national ICT policy [39]. However, there is a paucity of studies that have analysed the link between influence of external actors in the formulation of a national ICT policy and the context of a developing country. This paper is therefore intended to address this gap. In this paper, country context refers to economic, cultural, social and political status of a country at the time of formulating a national ICT policy.

\section{$3 \quad$ Theoretical Framework}

\subsection{Bourdieu's Theory of Practice (ToP)}

Bourdieu's framework focuses on aspects of domination and relative strength of agents (actors) within society [5], which was the interest of this study. Bourdieu understood domination in social space as primarily being prompted by unequal allocation of resources [5]. Examples of research that has adopted ToP are listed in Error: Reference source not found.

Table 2. A summary of studies that have used Bourdieu's theory of practice

\begin{tabular}{ll}
\hline Author(s)/Year & Research title \\
\hline Collyer et al., 2015 & Healthcare choice: Bourdieu’s capital, habitus and field \\
Gunter \& Forrester, 2009 & $\begin{array}{l}\text { School leadership and education policy-making in } \\
\text { England }\end{array}$ \\
Lingard et al., 2015 & $\begin{array}{l}\text { Researching the habitus of global policy actors in } \\
\text { education }\end{array}$ \\
\hline
\end{tabular}

The concepts of field, habitus, capital and practice (see Error: Reference source not found) are used to explain interactions of agents within a context [6]. Agents are distributed in the field based on the volume of capital they possess [6]. An agent is defined in the study as an individual, group of persons, donor or country who acts in a field such as national ICT policy formulation. 
A field is a network of relations with a specific distribution of power and has a boundary, a purpose to be achieved within some time frame and agents [28]. These agents go into the field with their habitus, which outlines their behaviour, beliefs and values in the field [12]. Bourdieu argued that an explanation of social phenomenon can be theorized by examining the social space in which interactions and events occurred [7]. Practices describe the actions of actors that are repeated and patterned [40]. Agents occupy positions, which are structured in terms of power relations.

The Malawi national ICT policy formulation was the field of study in which habitus of the actors was identified. Positions of actors in the field were identified based on the capital actors brought to the field.

Table 3. Concepts of Bourdieu's Theory of Practice

\begin{tabular}{lll}
\hline Concept & Definition & Examples \\
\hline Field & $\begin{array}{l}\text { A network of relationships of policy } \\
\text { actors and positions occupied as a } \\
\text { result of different forms of capitals } \\
\text { the actors possess [28]. }\end{array}$ & $\begin{array}{l}\text { A policy network and } \\
\text { relationships within the group }\end{array}$ \\
& $\begin{array}{l}\text { Actions that policy actors engage in, } \\
\text { or what they do. Habitus generates } \\
\text { Practice }\end{array}$ & Over-dependence on foreign aid \\
& $\begin{array}{l}\text { Behaviour, beliefs, values, } \\
\text { expressions of policy actors and are } \\
\text { Habitus }\end{array}$ & $\begin{array}{l}\text { Seeking external technical } \\
\text { identified through the practices that } \\
\text { enact the habitus [28] }\end{array}$ \\
& $\begin{array}{l}\text { Possessions of an actor [6] } \\
\text { Capital }\end{array}$ & $\begin{array}{l}\text { Cultural: skills, knowledge } \\
\text { Economic: funding }\end{array}$ \\
& & $\begin{array}{l}\text { Social: blueprint } \\
\text { Symbolic: tacit power }\end{array}$ \\
\hline
\end{tabular}

Bourdieu classifies capital into economic, social, cultural and symbolic capital [12]. Economic capital is about resources such as income or property; social capital as in connections [6], while cultural capital as knowledge and skills [7]. Bourdieu refers to symbolic capital as a form of tacit power that an agent holds and all the different forms of capital are interlinked. However, economic capital can be more easily and efficiently converted into cultural, social, and symbolic capital than the other way round [6].

\subsection{Limitations of the Theory}

Despite its wide use, Bourdieu's theory has some weaknesses. Bourdieu's theory does not clearly show "where to draw the line, that is, how to find out where the field ef fects stop" [28, p.78]. This limitation is associated with field boundary. This was addressed by specifying the time frame, purpose and actors that participated in the formulation of the policy within the context. Second, there is a problem of change in the field. Bourdieu theorized "fields as antagonistic, as sites of struggle. The game that is played in fields has no ultimate winner, it is an unending game, and this always implies the potential for change at any time” [28, p. 79]. To understand the existing form, Bourdieu stresses analysis of the way the field develops by showing how 
changes in the field take place over time [28]. The study analysed how policy formulation progressed within different sub-fields.

\section{$4 \quad$ Methodology}

\subsection{Approach}

This qualitative study adopted case study strategy to answer the research question, and used interviews and documents as the main methods of enquiry. Qualitative research provides an insight into some phenomenon of interest [42]. In addition, case study strategy was deemed necessary because it combines the phenomenon of interest and the context; and its aim is to provide an analysis of context and processes that may cause events associated with the occurrence of the phenomena [49]. The study sought to analyse how country context affects the influence of external actors in the ICT policy making. A case study uses multiple data gathering methods such as interviews and documents [3], which were used in this study.

Although some scholars posit that one cannot generalise on the basis of a single case [18], [20] argues that choice of a case, not necessarily the number of cases, is central in case study research and can be used to generalise to theory. Walsham [46] cited in [31, p.236] elucidates that with a "rich description of a case, the researcher can generalise to concepts, to a theory, to specific implications, or to rich insight. All four of Walsham's examples involve generalising from empirical statements (reflecting the observations made in a case study) to theoretical statements (concepts, theory, specific implications, and rich insight)". This study adopted the understanding of generalization to theory based on Walsham's [46] citation and used a single case study.

\subsection{Data Collection}

Nineteen (19) interviews (see Table 4) of policy actors who directly took part in the formulation of the national ICT policy and secondary data from draft national ICT policy documents, minutes of policy meetings and reports from the policy proceedings (see Error: Reference source not found5) between 2001 and 2009 were used.

Table 4. Summary of respondents

\begin{tabular}{ll}
\hline Sector & Respondent \\
\hline Academia & ACADEMIC-1 to 5 \\
Non-Governmental Organisation & NON-GOVERNMENTAL-1 \\
Private Sector & PRIVATE-1 to 4 \\
Public Sector & PUBLIC-1 to 6 \\
Public Sector & STATUTORY-1 to 3 \\
\hline
\end{tabular}

Influence of external actors was studied within three nested policy making fields in the context. The first field constituted policy making activities that took place between 2001 and 2003, the second from 2004 and 2006 whilst the third field was the draft ICT policy between 2007 and 2009. 
Table 5. Secondary data sources

\begin{tabular}{llll}
\hline Unit of interest & Primary data & Secondary data \\
\hline Local actor & $\begin{array}{l}\text { Semi-structured interviews with 18 } \\
\text { respondents }\end{array}$ & $\begin{array}{l}\text { Three workshop reports } \\
\text { [17]; [29]; [34] and two } \\
\text { copies minutes of policy } \\
\text { meetings [22]; [23] }\end{array}$ \\
$\begin{array}{ll}\text { National } \\
\text { policy }\end{array}$ & $\begin{array}{l}\text { Three versions of draft policies (2003, } \\
\text { 2006 and 2009) }\end{array}$ & None \\
\hline
\end{tabular}

\subsection{Data Analysis}

Thematic analysis was applied in an iterative manner to code the data using six phases [9]. (see Error: Reference source not found). Informed by Bourdieu's concepts of field, capital, habitus and practice, an initial set of eight codes was developed and refined using the first three interview transcripts. The 8 codes were subsequently applied on the remaining 15 interview transcripts and relevant policy documents in a process that resulted in 23 codes.

Table 6. Phases of thematic analysis [9, p.87]

\begin{tabular}{|c|c|}
\hline Phase & Description of the process \\
\hline $\begin{array}{l}\text { Familiarizing } \\
\text { yourself with your } \\
\text { data }\end{array}$ & $\begin{array}{l}\text { Transcribing data (if necessary), reading and re-reading the data, } \\
\text { noting down initial ideas. }\end{array}$ \\
\hline $\begin{array}{l}\text { Generating initial } \\
\text { codes }\end{array}$ & $\begin{array}{l}\text { Coding interesting features of the data in a systematic fashion } \\
\text { across the entire data set, collating data relevant to each code. }\end{array}$ \\
\hline Searching for themes & $\begin{array}{l}\text { Collating codes into potential themes, gathering all data relevant } \\
\text { to each potential theme. }\end{array}$ \\
\hline Reviewing themes & $\begin{array}{l}\text { Checking if the themes work in relation to the coded extracts } \\
\text { (Level 1) and the entire data set (Level 2), generating a thematic } \\
\text { 'map' of the analysis. }\end{array}$ \\
\hline $\begin{array}{l}\text { Defining and naming } \\
\text { themes }\end{array}$ & $\begin{array}{l}\text { Ongoing analysis to refine the specifics of each theme, and the } \\
\text { overall story the analysis tells, generating clear definitions and } \\
\text { names for each theme. }\end{array}$ \\
\hline Producing the report & $\begin{array}{l}\text { The final opportunity for analysis. Selection of vivid, compelling } \\
\text { extract examples, final analysis of selected extracts, relating back } \\
\text { of the analysis to the research question and literature, producing a } \\
\text { scholarly report of the analysis. }\end{array}$ \\
\hline
\end{tabular}

An examination of the codes revealed 4 overarching themes of context of policy formulation, interaction among actors, domination of actors and behaviour of policy actors. NVIVO 11 software was used during the analysis. The theme on context of policy formulation is the focus of this paper. 


\subsection{Limitations of the Methodology}

The policy making process in Malawi took place more than ten years ago so memory lapses were a limitation as some policy actors could not recall some of the events of the policy process [42]. This was partly addressed by sending copies of the research instrument and draft policy documents prior to the interviews. This was done to assist the actors to recall some of the events that took place years back based on the contents of the draft policy documents.

Another limitation arose when the Ministry responsible for ICT could not trace minutes for policy proceedings. This was mitigated by contacting some of the policy actors who had kept few copies of the policy meetings. A third limitation arose when most of the external actors failed to trace individuals who took part in the policy making arena. Snowballing was used to identify some roles that the external actors played during policy making. However, while some of the local actors presented their personal views about the roles of the external actors, their level of subjectivity could affect the accuracy of the findings since the local actors' views on the behaviour of external actors during the process could not be validated.

\section{$5 \quad$ Case Description: Malawi Context}

\subsection{Country’s Historical and Political Perspectives}

Malawi, a country located in East Africa, gained its independence from Great Britain in 1964 [, the first national ICT policy for the country was only launched under Joyce Banda’s presidency [24].

At the time of formulating the national ICT policy, Malawi had been facing challenges in most spheres of life such as illiteracy levels at $81 \%$, population growth rate at $3.2 \%$ and lack of access to higher education for the vast majority [17].

\subsection{Malawi Public Policy Making Process}

Malawi adopts the standard public policy approach described in Section 2.1. This process starts with identification of an issue, followed by the development of a concept paper that would address the problem. Next, stakeholder consultations are held followed by formulation of the policy document, which is reviewed by cabinet. Once cabinet approves, the policy is ready for implementation. Beyond implementation stage, issues of monitoring and evaluation arise [33]. TheError: Reference source not found policy process may iterate at any of the stages.

\subsection{Malawi National ICT Policy}

The first activities to developing a national ICT policy started in 2001 when UNDP funded a pre-policy survey [29] and pre-policy workshops in 2002 [34]. The workshops recommended adoption of a UNECA framework, which was used in developing the country’s first draft policy. An Information Technology Task Force 
(ITTF) consisting of public and non-public actors (private and non-governmental organisations) led the activity while the second and third draft policies were led by a National ICT Working Group (NICTWG), which replaced the ITTF. In subsequent drafts, the country abandoned the framework and took a national approach to policy formulation. Although the name of the second draft policy was ICT4D, in the context it was the ICT policy. The three draft policies are summarised in Table 7.

Table 7. A summary of purpose and custodian of the policy

\begin{tabular}{|c|c|c|}
\hline Version of policy & Purpose & $\begin{array}{l}\text { Custodian of } \\
\text { policy }\end{array}$ \\
\hline $\begin{array}{l}\text { First draft national ICT } \\
\text { policy }(2001-2003)\end{array}$ & $\begin{array}{l}\text { Contribute to the attainment of the aspirations of } \\
\text { the Vision 2020, the objectives of the Malawi } \\
\text { Science and Technology Policy, and the } \\
\text { objectives of Malawi Poverty Reduction Strategy } \\
\text { paper [25, p.7] }\end{array}$ & ITTF \\
\hline $\begin{array}{l}\text { Second draft national } \\
\text { ICT policy (2004 - } \\
\text { 2006) }\end{array}$ & $\begin{array}{l}\text { Provide a framework for deployment, } \\
\text { exploitation and development of ICTs to support } \\
\text { the process of accelerated socio-economic } \\
\text { development in Malawi [26, p.2] }\end{array}$ & NICTWG \\
\hline $\begin{array}{l}\text { Third draft national } \\
\text { ICT policy (2007 - } \\
\text { 2009) }\end{array}$ & $\begin{array}{l}\text { Provide a framework for deployment, } \\
\text { exploitation and development of ICT to support } \\
\text { the process of accelerated socio-economic } \\
\text { development in Malawi }[27, \mathrm{p} .6]\end{array}$ & NICTWG \\
\hline
\end{tabular}

\subsection{Challenges Affecting the ICT Sector in the Country}

Malawi is characterised by an underdeveloped ICT infrastructure, lack of skilled and experienced human resources in policy formulation, a weak information and computer use culture, high cost of telecommunications and unstable and unreliable power [17]. Given these challenges, Malawi has continued to rely on financial and technical support on most of its projects [48].

\section{$6 \quad$ Results}

The research sought to analyse the link between country context and external actors' influences in the formulation of a national ICT policy in developing countries using Malawi as the context.

\subsection{Policy Formulation Field}

Policy formulation constituted three overlapping nested fields (see Error: Reference source not found1), which were: (i) draft national ICT policy of 2003, (ii) draft Malawi National ICT for Development (ICT4D) policy of 2006 and (iii) draft national ICT policy of 2009. Each draft policy had a temporary boundary, a purpose to be achieved in a time frame and a policy network that occupied different positions in the field (See Table 8). Two additional fields shared relationships with the three policy making fields. These are political field, occupied by cabinet, and external actors' 
field, in which most of the external influences were located (see Figure 1). While the political field was nested within the second and third draft policy fields; the other field was nested within all the three fields.

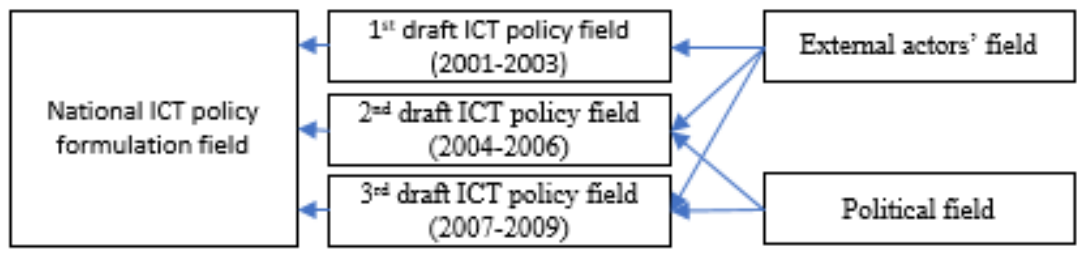

Figure 1: Overview of overlapping and nested fields of ICT policy formulation in Malawi

With some level of autonomy and its own logics [7] , a field generates "its own values and behavioural imperatives that are relatively independent from forces emerging from the economic and political fields" [38, p.458]. The national ICT policy field was not completely autonomous. The control from the external actors' and political fields reduced the autonomy of the field. This control created cross-field effects and affected the policy process: “...when the template was thrown out. ... and [the] policy approach changed from UNECA to [take a] national [stance], that's what has worked [for the nation]" (NON-GOVERNMENTAL-1).

\subsection{Context of Policy Formulation (2001-2009)}

The theme on context of policy formulation revealed that the ITTF omitted challenges associated with country context in the first draft, which adopted the NICI framework. However, the NICTWG acknowledged the contextual challenges in the second and third draft policies. For example, in the first draft policy there was little mention of illiteracy as having an impact on access to and usage of ICTs. Although the draft policy mentioned literacy issues as in "Promote basic literacy and ICT literacy in Malawi" [25, p.13], the policy was silent about the country's illiteracy levels as a challenge relating to ICTs. Similarly, poverty was only mentioned in the context of another policy paper: "Furthermore, the conviction is demonstrated through Government's prioritization of ICT activities in the Malawi Poverty Reduction Strategy Paper" [25, p.6]. In addition, contextual challenges such as energy were also omitted in the first draft policy although one respondent felt that: "...energy [electricity] and poverty were not considered at the time of developing [the] policy" (PRIVATE-1).

Economic and cultural capital have the potential to affect policy outcomes [13]. Thus, the habitus of omitting challenges of the country shaped the policy making field. This could mean that the policy team was inexperienced and failed to appreciate the importance of context in policy formulation. Alternatively, it could be that the NICI framework was so over-powering, so they failed to customise it to the case of Malawi.

The NICTWG considered country context during the second draft policy: 
“...Malawi faces a number of challenges that must be taken into account in order to achieve sustainable development processes and outcomes and promote the development and use of ICT. More often such challenges have affected and derailed the implementation of policies and strategies on one hand and intended outcomes, on the other" [26, p.7].

Likewise, in the third draft policy, challenges in the context were acknowledged: "socio-economic challenges which are associated, among other things, with inadequate communication infrastructure, very low utilization of technology and lack of information" [27, p.6].

Despite acknowledging the challenges such as over-dependence on aid, the local actors still considered donor support as a strategy to implement policy objectives: "Encourage donor agencies, non-government organizations and other development partners of the country to help in ICT capacity building initiatives" [26, p.31]. In other words, an identified challenge becomes a solution at the same time.

External actors may have taken advantage of the practice of over-dependence on foreign aid, for example, and played other roles than the tradition of providing financial and technical support [10]. (see Table 8Error: Reference source not found). The different pre-policy activities that were funded by external actors constituted agenda setting. Funding is classified as economic capital [6]. The importance of agenda setting as a foundation of policy making has been noted. Problems in agenda setting may bring forth undesired effects for the policy process and policy outcomes (Fox et al., 2006). The agenda for ICT policy making in Malawi was set by external actors: "... a donor came and said there are issues of an ICT policy so a donor came and said we will fund it, hence Malawi did not own the policy" (PRIVATE-1). This may suggest that the context was not ready for the policy. A summary of the capital, habitus and practices identified in the context is in Figure 2. Donor dependency syndrome negatively affects realisation of policy outcomes [48].

Government requested UNECA to provide technical assistance in the context, which was in a form of customizing the NICI framework. Many respondents expressed lack of technical skills in policy formulation as the reason why government sought external support: "[there was] admission that the country did not have skills in policy formulation hence [government] called for assistance" (PUBLIC-5). In this case, the habitus of seeking external technical support shaped the policy. 


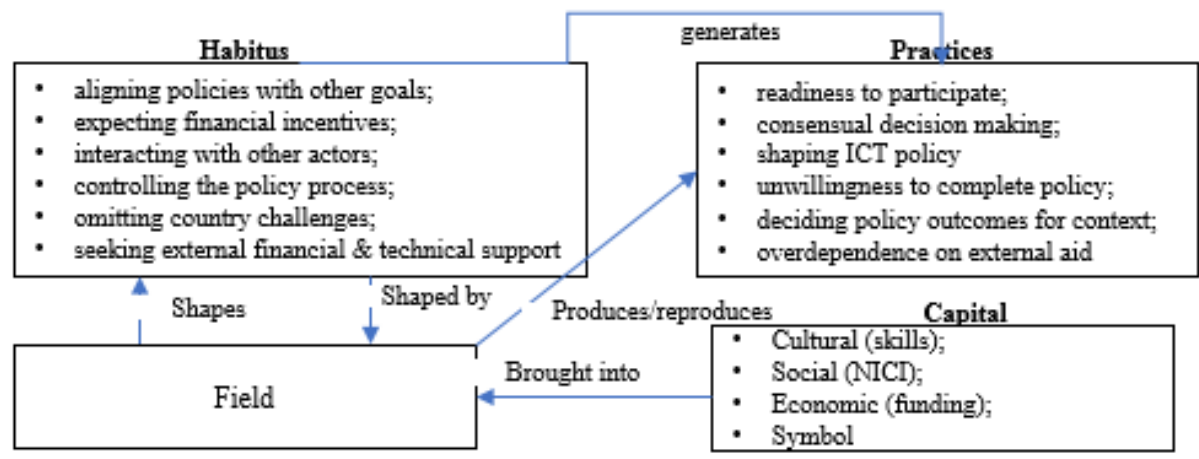

Figure 2. A summary of the capital, habitus and practices in the context

\section{$7 \quad$ Discussion and Conclusion}

External actors played different roles in the context because of the capital they brought into the policy making field, which shaped the design and process of the national ICT policy (see Error: Reference source not foundError: Reference source not found). The context did not appear to have sufficient economic capital compared to the external actors' financial resources. Bourdieu identifies economic capital as resources such as income or property [6]. Some respondents said that the habitus of expecting donor support pushed government to accept funding from external actors towards initiatives although these were not priorities of government at the time. For example, government received funding from the World Bank for formulation of a Universal Access policy at a time implementation of the policy could not be sustained. In this case, an external actor played the role of setting a priority for the context.

Acceptance of this funding may be attributed to the country's overdependence on donor aid, a practice that is produced and reproduced in the context. This agrees with literature that $40 \%$ of the country's annual budget year-in and year-out is supplemented by foreign aid [36]; [48]. Some respondents said that an external actor partnered with a local actor through provision of funding and controlled formulation of the Universal Access policy. This supports literature that: "Through these funding partnerships, donors can sometimes control policy agendas and project ideas" [10, p.94]. External actors' actions may have led to abandonment of and delays in launching the policy. Indeed, the first draft policy was later abandoned in favour of local initiatives within the context. Furthermore, formulation of the national ICT policy was also prolonged as the final policy was only launched more than 10 years later.

At the time of formulating the national ICT policy, the country context was experiencing economic challenges such as severe poverty and heavy dependence on donor assistance [17]. This appears to suggest that the context had limited economic capital. Thus, setting priorities for such a country may overburden government to allocate financial resources, in this case economic capital, on projects that are not sustainable or 
cannot be implemented. Setting policy priorities in such a country may "contribute to policy fragmentation, overburden local administrations and tie up scarce professional resources" [2, p.36] and contradicts literature that donors and partners should focus their efforts around "country-owned and defined objectives and expected results" [50, p.9].

Some respondents observed that an external actor shaped the content of an ICT policy in the context through provision of a blueprint as a tool for developing a national ICT policy. The blueprint was a resource that was adopted in the context in the formulation of the policy. Bourdieu describes social capital as a resource that is connected with group membership and social networks but is also based on mutual understanding and appreciation among agents [6]. Some respondents mentioned that they did not support adoption of the blueprint because they did not share the idea of using the blueprint. This is consistent with literature that imposing ideas on a country may fail to produce the desired output [44]. Other respondents accepted that the blueprint was useful as it worked as an eyeopener given that the context did not have the knowledge and skills to develop a national ICT policy. The different viewpoints may have resulted in unintended policy outcomes since decisions among the local actors were made through consensus. Indeed, after a while, local actors abandoned the blueprint and took a different approach to policy making. This was despite the context holding several sensitisation workshops seeking views of different stakeholders on the suitability of blueprint in the context. This may mean that the country context did not fully support adoption of the blueprint on account of limited social capital with respect to the blueprint.

Table 8. Roles of external actors in the Malawi policy field vis-à-vis traditional roles

\begin{tabular}{lll}
\hline $\begin{array}{l}\text { Forms of } \\
\text { capital }\end{array}$ & External actor(s) & Roles of external actors \\
\hline $\begin{array}{l}\text { Economic } \\
\text { capital }\end{array}$ & UNDP, COMESA, the World & Providing financial resources \\
Cultural & Bank & \\
capital & Uxternal consultants & Setting policy priorities \\
& Bank & Facilitating entry of external actors \\
Social capi- & UNECA & \\
tal & UNECA, Rwanda & Shaping of policy content \\
\cline { 2 - 3 } & & Shaping of policy formulation \\
\end{tabular}

Most respondents also acknowledged that the context did not possess sufficient knowledge and skills for formulating a national ICT policy. Bourdieu identifies knowledge and skills as a category of cultural capital [7]. So, as a starting point, government made a request to external actors to provide technical support in policy making. External actors also recruited consultants to offer technical support during policy activities in the context. In this way, external actors facilitated entry of other actors into the policy making arena through provision of technical support, which was in limited supply in the context. There was admission that the local actors did not have cultural capital at the time for developing a national ICT policy. The country's lim- 
ited cultural capital in the field shaped the habitus of seeking external technical support, which in turn generated the practice of overdependence on foreign aid.

Because of the country's limitations, external actors brought economic, social and cultural capital during policy formulation field and played roles that contradict literature on the tradition of providing financial and technical support in projects [10]. The different forms of capital that were identified in the policy making space constituted the context. External actors brought sufficient economic, social and cultural capital in the country context at the request of government. This agrees with literature that all the different forms of capital are inter-linked [6].

This discussion leads to a proposition that:

P1 When the context of a country is characterised by limited economic, social and cultural capital during formulation of a national ICT policy then external actors play other roles in the context that result in unintended policy outcomes than the tradition of providing funding and technical support

In summary, Bourdieu's concepts of field, capital and habitus have been used to illuminate the field in which formulation of a national ICT policy took place. The major tools used in this paper are field and capital. The study has found that when the context of a developing country has limited economic, social and cultural capital then external actors such as donors, international organisations take advantage of the context and play roles other than the tradition of providing funds and technical support. External actors shape policy formulation, content of a policy but also set priorities which are not on the government's agenda. These roles in turn affect other stages of the policy process. A limitation in this study was that the research focused on a single case, which may give a narrow view. Future research may consider comparing contexts from more developing countries to broaden the view.

\section{References}

1. Adam, L., \& Gillwald, A. (2007). The Political Economy of ICT Policy Making in Africa: Historical Contexts of Regulatory Frameworks, Policy Performance, Research Questions and Methodological Issues. London: The Association for Information Management.

2. Altenburg, T. (2010). Industrial Policy in Developing Countries: Overview and lessons from seven country cases. Born: German Development Institute.

3. Benbasat, I., Goldstein, D. K., \& Mead, M. (1987). The Case Research Strategy in Studies of Information Systems. MIS Quarterly, 11(3), 369-386.

4. Birkland, T. A. (2015). An Introduction to the Policy Process: Theories, Concepts, and Models of Public Policy Making (Third Edition ed.). New York: Routledge.

5. Bourdieu, P. (1977). Outline of a Theory of Practice. Cambridge: Cambridge University Press. 
6. Bourdieu, P. (1986). The Forms of Capital. In J. G. Richardson, Handbook for Theory and Research for the Sociology of Education (pp. 241-258). Cambridge: Polity Press.

7. Bourdieu, P. (2005). The Social Structures of the Economy. (C. Turner , Ed.) Cambridge: Polity Press.

8. Bourdieu, P., \& Wacquant, L. J. (1992). An Invitation to Reflexive Sociology. Cambridge: Polity Press.

9. Braun, V., \& Clark, V. (2006). Using thematic analysis in psychology. Qualitative Research in Psychology, 3(2), 77-101.

10. Chiumbu, S. H. (2008, February 1). Understanding the Role and Influence of External Actors and Ideas in African Information, Communication and Technology Policies: The African Information Society Initiative. PhD Thesis. Oslo, Oslo, Norway: University of Oslo.

11. Cloete, F., Wissink, H., \& De Coning, C. (2006). Improving public policy: From theory to practice. London: Van Schaik Publishers.

12. Collyer, F. M., Willis, K. F., Franklin, M., Harley, K., \& Short, S. D. (2015). Healthcare choice: Bourdieu's capital, habitus and field. Current Sociology Monograph, 63(5), 685699.

13. Diga, K., Nwaiwu, F., \& Plantinga, P. (2013). ICT policy and poverty reduction in Africa. Emerald, 15(5), 114 - 127.

14. Dodge, K. A. (Ed.). (2011). Context Matters in Child and Family Policy. Child Dev., 82(1), 433-442.

15. Dye, T. R. (2013). Understanding Public Policy (Forteeth Edition ed.). New York: Pearson Education, Inc.

16. Dzidonu, C. (2002). A Blueprint for Developing National ICT Policy in Africa. African Technology Policy Studies Network, 1-35.

17. Dzidonu, C. (2002b). An Integrated Socio-Economic and ICT Policy. Lilongwe: United National Economic Commission for Africa.

18. Eisenhardt, K. M., \& Graebner, M. E. (2007). Theory Building from Cases: Opportunities and Challenges. The Academy of Management Journal, 25-32.

19. Etta, E. F., \& Elder, L. (2005). At The Crossroads: ICT Policy Making in East Africa. Nairobi: East African Educational Publishers.

20. Flyvbjerg, B. (2006). Five Misunderstandings About Case-Study Research. Qualitative Inquiry, 219-245.

21. Gillwald, A. (2010). The Poverty of ICT Policy, Research, and Practice in Africa. Cape Town: University of Cape Town.

22. GoM1. (2001, January 18). Minutes of the Second Meeting of the Information Technology Task Force held on 18 January, 2001. Blantyre, Malawi.

23. GoM2. (2001b, July 25). Minutes of the Second Meting of Information Technology Task Force. Lilongwe.

24. GoMICTF. (2013). National ICT Policy: An ICT-led Malawi. Lilongwe: Republic of Malawi.

25. GoMICTP1. (2003). Malawi Information and Communications Technology (ICT) Policy. Lilongwe: Malawi Government.

26. GoMICTP2. (2006). Malawi National ICT for Development (ICT4D) Policy. Lilongwe: Government of Malawi.

27. GoMICTP3. (2009). National ICT Policy: An ICT-led Malawi. Lilongwe: Government of Malawi.

28. Grenfell, M. (2008). Pierre Bourdieu: Key Concepts. Durham: Acumen Publishing Limited. 
29. Kanjo, C., \& Mtema, P. (2003). Role of ICT in Poverty Reduction at national and district levels in Malawi: final report. Lilongwe: UNDP.

30. Kunyenje, G., \& Chigona, W. (2017). External actors' influence on national ICT policy in developing countries: A literature review. ACIST 2017 (pp. 1-10). Cape Town: ACIST 2017.

31. Lee, A. S., \& Baskerville, R. L. (2003). Generalizing Generalizability in Information Systems Research. Information Systems Research, 14(3), 221-243.

32. Lubua, E., \& Maharaj, M. (2012). ICT Policy and e-Transparency in Tanzania. IST-Africa 2012 Conference Proceedings (pp. 1-10). ResearchGate.

33. Makoza, F. (2017, February). Power relations among stakeholders in the implementation of National ICT Policy: Case of Malawi. PhD Thesis. Cape Town, South Africa: University of Cape Town.

34. Mbvundula, T. P. (2003). Report on Country-wide Consultations for An Integrated Socio-Economic and ICT. Lilongwe: UNDP.

35. Metfula, A. S. (2013, January 1). The interplay between policy network actors and information and communication technology policies in a developing country context. $P h D$ Thesis. Cape Town, Cape Town, South Africa: University of Cape Town.

36. Mkamanga, E. (2018, February 27). Malawi 'losing' sovereignity. Retrieved from The Nation: http://mwnation.com/malawi-losing-sovereignity/

37. Moran, M., Rein, M., \& Goodin, R. E. (2006). The Oxford Handbook of Public Policy. Oxford: Oxford University Press.

38. Naidoo, R. (2004). Fields and institutional strategy: Bourdieu on the relationship between higher education, inequality and society. British Journal of Sociology of Education, 25(4), 457-471.

39. Odongo, A. O. (2012). ICT Policy in Africa - A Comparative Study of Ghana and Kenya Drawing on Lessons from Developed Countries. Computers and Society, 192-201.

40. Schultze, U., \& Boland, Jr., R. J. (2000). Knowledge management technology and the reproduction of knowledge work practices. Journal of Strategic Information Systems, 193212.

41. Schuppan, T. (2009). E-Government in developing countries: Experiences from sub-Saharan Africa. Government Information Quarterly, 26, 118-127.

42. Silverman, D., \& Marvasti, A. (2008). Doing qualitative research. Thousand Oaks, CA: Sage. London: Sage Publications.

43. Spyridaki, N.-A., Ioannou, A., \& Flamos, A. (2016). How Can the Context Affect Policy Decision-Making: The Case of Climate Change Mitigation Policies in the Greek Building Sector. Energies, 9(294), 1-22.

44. Stiglitz, J. E. (2002). Participation and development: Pesrpectives from the Comprehensive Development Paradigm. Review of Deevelopment Economics, 6(2), 163-182.

45. Thompson, M., \& Walsham, G. (2010). ICT Research in Africa: Need for a Strategic Developmental Focus. Information Technology for Development, 16(2), 112-127.

46. Walsham, G. (1995b). Interpretive case studies in IS research: Nature and method. European Journal of Information Systems, 74-81.

47. World Bank. (2016, October 6). Doing Business. Retrieved from World Bank: http://documents.worldbank.org

48. Wroe, D. (2012). Briefing Donors, Dependency, and Political Crisis in Malawi. African Affairs, 1-10.

49. Wynn, Jr., D., \& Williams, C. K. (2012). Principles for Conducting Critical Realist Case Study Research in information Systems. MIS Quarterly, 36(3), 787-810. 
50. Yizengaw, T. (2005). Policy development in higher education in Ethiopia and the role of donors and development partners. International Expert Meeting 'A Changing Landscape', 23-25 May 2005 (pp. 1-12). The Hague: Nuffic Conference 